\title{
KRITIK HADITS DALAM KAWASAN KAJIAN SEJARAH
}

\author{
Rahmi \\ UIN Imam Bonjol Padang \\ E-mail: rahmi@uinib.ac.id \\ Taufiqurrahman \\ UIN Imam Bonjol Padang \\ E-mail: taufiqurrahman@uinib.ac.id
}

\begin{abstract}
The position of hadith criticism is explicitly directed at the criticism of sanad (external criticism; naqd al-khariji) and matan criticism (internal criticism; naqd aldakhili) basically based on the existence of hadith as the second source which needs to be maintained so that there is an assessmentcritics of the narrators have a purpose to determine the acceptance or rejection of their narrations which are equipped with comprehensive data about the rawi assessed. in this case it is very possible for various approaches, such as the historical approach as a study area, even the approaches of other social sciences as an effort to understand the behavior formed by certain positions in society. in other words, Scientific Kum Doktriner; do not see the doctrinal aspects of sich, but also the scientific aspects.
\end{abstract}

Keywords: Hadith criticism, existence of hadith, historical approach

\section{Pendahuluan}

Kesetiaan untuk membela hadits sebagai salah satu sumber ajaran Islam, dalam perjalanan sejarahnya, ternyata membawa implikasi yang melahirkan bibit-bibit ilmiah sehingga dalam perkembangannya dapat dirumuskan menjadi suatu disipilin ilmu, yang dikenal dengan Ulumul Hadits. Potensi ilmiah ini dimplikasikan pada sistem sanad dalam periwayatan hadits, yang pada gilirannya terakumulasi secara epistemologis dalam Ilmu Jarh dan Ta'dil, dan sekaligus merupakan lahan kegiatan Naqd al-Sanad, Kritik Sanad. Atas dasar itu, paling tidak ada dua objek lahan kajian dalam penelitian hadits yang mencakup aspek penelitian sanad dan penelitian matan. Dalam kaitan ini, para ulama sepakat memposisikan sanad sebagai aspek yang dominan serta menempat-kannya pada kedudukan terpenting dalam penelitian hadits. Bahkan, di antara ulama ada yang berpandangan ekstrim, seperti Ibn Chaldun dan Ahmad Amin, bahwa yang dimaksud dan yang ingin dicapai dalam penelitian hadits hanya meneliti sanad an sich, bukan pada aspek matan-nya ${ }^{1}$. Pandangan seperti ini juga ditopang dengan pernyataan Imam al-Nawawiy yang menjelaskan bahwa hubunngan sanad dengan hadits

${ }^{1}$ Ibn Chaldun, Muqaddimah, Beirut, Dar al-Fikr, T.th., h. 27, lihat Ahmad Amin, Fajr al-Islam, Kairo, Maktabah al-Nahdhah alMishriyat, 1974, h. 217-218. 
diibaratkan hewan dengan kakinya ${ }^{2}$, serta pernyataan Sufyan al-Tsauriy mengibaratkan seperti senjata bagi orang beriman ${ }^{3}$.

Anggapan dan asumsi yang berkembang dari kalangan ulama di atas wajar saja muncul, dengan alasan bahwa mereka memandang urgensi dan posisi penelitian sanad dalam hadits lebih diutamakan, sehingga penelitian sanad tersebut tampak jelas sebagai format utama dalam upaya menilai kualitas dan validitas suatu hadits. Oleh sebab itu, proses kerja dalam penelitian sanad sangat mendukung dalam mencapai tujuan kesahihan hadits. Di lain pihak, penelitian sanad dilakukan karena adanya faktor internal yang memotivasi pelaksanaan penelitian tersebut. Sebagaimana dikemukakan oleh M. Syuhudi Ismail, bahwa ada dua hal yang melatarbelakangi pelaksanaan penelitian sanad, yaitu: melihat kesumberan hadits dalam ajaran Islam, dan faktor sejarah hadits itu sendiri. Lebih lanjut Syuhudi Ismail menjelaskan faktor pertama sangat erat kaitannya bahwa hadits merupakan salah satu sumber ajaran Islam. Sedangkan faktor kedua pentingnya penelitian sanad hadits karena dalam perjalanan sejarahnya muncul tragedi dan inovasi. Hal ini dapat dimaklumi bahwa tidak seluruh hadits tertulis. Sesudah zaman Nabi berkembang upaya pemalsuan hadits. Sementara itu, kegiatan penghimpunan hadits secara resmi dan massal terlaksana setelah berkembanganya pemalsuan-

\footnotetext{
${ }^{2}$ Abu Zakaria Yahya al-Nawawiy, Shahih Muslim bi Syarh al-Nawawiy, Kairo, Maktabah al-Mishriyat, 1924, h. 88.

${ }^{3}$ Nuruddin 'Itr, Manhaj al-Naqd fiy 'Ulum al-Hadits, Damaskus, Dar al-Fikr, 1979, h. 344 .
}

pemalsuan hadits ${ }^{4}$. Dengan demikian, kedua motivasi ini merupakan basis dalam rangkan mengoptimalkan pelaksanaan penelitian sanad hadits, bahkan melakukan pelacakan keotentikan sumber hadits.

$$
\text { Dalam tinjauan historis, }
$$

dinamika penelitian sanad hadits sempat mencapai puncaknya dan merupakan referensi khusus serta menjadi data otentik sejarah dalam pelaksanaan penelitian hadits berikutnya. Oleh sebab itu, dalam tulisan ini diupayakan menyingkap kembali warisan-warisan "yang mungkin sempat dimuseumkan" dengan dilandasi pada analisis kritis dalan aspek rumusan dan operasional kritik sanad hadits. Di samping itu, melalui kaca mata sejarah akan disoroti perkembangan periode klasik dalam kaitannya dengan Ilmu Jarh dan Ta'dil. Perlu juga dimaklumi bahwa ada bagian tertentu sebagai "notabene", meskipun tidak tertulis, terhadap perkembangan pemikiran dari kalangan orientalis yang melahirkan hipotesis baru yang sangat kontroversial. Fenomena ini merupakan "home work" bagi seluruh umat Islam dalam rangka menyikapi dinamika pemikiran yang kritis dalam konteks kekinian.

\section{Pola Penerapan Kritik Sanad}

Dalam kajian dan penelitian hadits, kritik sanad menempati posisi untuk menilai bahkan membuktikan secara real bahwa secara historis sesuatu yang dikatakan hadits tersebut dapat diyakini berasal dari Nabi SAW. Di lain sisi, dari kacamata sejarah,

\footnotetext{
${ }^{4}$ M. Syuhudi Ismail, Kaedah Kesahihan Sanad Hadis, Telaah Kritis dan Tinjauan dengan Pendekatan Ilmu Sejarah, Jakarta, Bulan Bintang, 1988, h. 75.
} 
ternyata telah membaur dampak politik yang ada terhadap kekisruhan dalam periwayatan hadits melalui jalaur sanad, sehingga hal ini menuntut adanya suatu sistem dan metode yang sistematis guna melahirkan kaedah atau standar kesahihan suatu sanad dalam periwayatan hadits. Tegasnya, objek kajian dari kritik sanad secara esensial ditujukan kepada yang dikategorikan sebagai hadits "Ahad", bukan hadits "Mutawatir". Kategori ini dimaksudkan bahwa hadits yang "mutawatir" sudah disepakati telah mencapai standar validitas kesahihan sanad-nya sampai kepada tingkat Nabi SAW. Sebaliknya, terhadap hadits "Ahad" masih ada kecenderungan yang meragukan tingkat validitasnya. Dengan demikian, untuk mencapai tingkat standar validitas kesahihan sanad hadits, maka hadits "Ahad" itu sendiri perlu memenuhi beberapa persyaratan optimal yang disepakai oleh para ulama. Dalam kaitan ini, para ulama merekomendasikan perlu diadakan penelitian dalam bentuk kritik sanad, atau biasa juga disebut sebagai Naqd al-Sanad atau Naqd al-Kharijiy (kritik Ekstern).

Kritik sanad atau kritik ekstern yang merupakan telaah ulang atas prosedur periwayatan hadits melalui jalur sanad dari seluruh perawi yang secara berantai menyampaikan matan hadits sampai kepada perawi akhir. Oleh sebab itu, validitas kesahihan sanad hadits dapat diukur melalui lima kriteria, yaitu sanad bersambung, seluruh perawi dalam jalur sanad bersifat 'adil, seluruh perawi dalam jalur sanad bersifat dhabith, sanad hadits terhindar dari syadz dan sanad hadits terhindar dari 'illat. Rincian kriteria ini dapat diuraikan sebagai berikut:

\section{Sanad Bersambung}

Shubhi al-Shalih dalam bukunya 'Ulum al-Hadits wa Mushthalahuhu menjelaskan bahwa sanad bersambung atau "Ittishal" adalah setiap perawi dalam jalur sanad hadits menerima riwayat hadits dari perawi terdekat sebelumnya; keadaan demikian berlangsung sampai pada akhir sanad di dalam periwayatan hadits tersebut ${ }^{5}$. Bertitik tolak dari pemahaman ini dapat dipahami bahwa kebersambungan sanad hadits diperlukan guna memastikan bahwa matan hadits yang diriwayatkan memang berasal dari Nabi SAW. Artinya, bila terjadi keterputusan jalur sanad dan ketidaklayakan seorang perawi membawa akibat kepada matan hadits yang diriwayatkannya ditolak dan tingkat kesahihan hadits tersebut akan mengalami penurunan. Dalam kaitan ini, metode kritis yang dapat diterapkan guna meneropong kebersambungan sanad hadits tersebut adalah $^{6}$ :

Pertama, mencatat semua perawi yang terdapat di dalam jalur sanad.

Kedua, mempelajari biografi dan aktivitas kelimuan dari masingmasing perawi. Untuk dimaklumi, ketika menggunankan kitab-kitab klasik, maka setelah dijelaskan biografi seorang perawi akan diketemukan katakata روى عـن "rawa 'an" (siapa gurunya) dan روي عند "ruwiya 'anhu" (siapa muridnya). Ketika menggunakan fasilitas digital library, akan diketemukan kata-kata suyukh (para

${ }^{5}$ Shubhi al-Shalih, 'Ulum al-Hadits wa Mushthalahuhu, Beirut, Dar al'Ilm li alMalayin, 1977, h. 145.

h. 112 . 
guru) dan talamidz (para murid) dari seorang perawi.

Ketiga, mengkaji kata-kata yang digunakan sebagai penghubung antara seorang perawi dengan perawi yang terdekat dalam satu jalur sanad. Sebagai contoh, apakah kata-kata yang digunakan dengan lafaz haddatsana (haddatsani), akhbaran (akhbarani), 'an dan lain-lainnya.

Setelah metode tersebut di atas diterapkan akan diperoleh suatu kesimpulan tentang status dan posisi dari hubungan masing-masing perawi pada jalur sanad yang diteliti. Sebaliknya, untuk menilai keterputusan (tidak bersambungnya) sanad dalam satu jalur sanad hadits dapat dilihat dari beberapa kategori berikut ini:

Pertama, gugurnya sanad, baik pada tingkat sahabat (mursal), tingkat tabi'in (mu'allaq); dengan jumlah perawi yang gugur dua atau secara berurutan (mu'dal) dan tidak secara berurutan (munqathi').

Kedua, adanya bukti bahwa seorang perawi yang menerima hadits tidak pernah berkunjung atau bertemu ke tempat orang yang menyampaikan hadits tersebut. Bisa jadi dalam kasus tertentu, seorang yang menyampaikan hadits telah meninggal dunia, sementara yang menerima hadits belum lahir. Kajian terhadap kasus-kasus seperti ini menuntut perlunaya penguasaan riwayat hidup (kelahiran dan wafatnya) seorang perawi serta berbagai daerah yang pernah dikunjungi.

\section{Perawi Bersifat 'Adil}

'Adil dalam kajian Ilmu Hadits, sebagaimana dijelaskan oleh Jalal alDin 'Abd al-Rahman Ibn Bakr alSuyuthi terangkum dalam empat kriteria khusus, yaitu beragama Islam, mukallaf, tidak fasiq dan selalu menjaga muru'ah ${ }^{7}$. Dengan demikian, metode kritik yang dapat diterapkan dalam menyoroti 'adil-nya seorang perawi adalah sebagai berikut ${ }^{8}$ :

Pertama, melihat popularitas dan kemuliaan seseorang dalam kedudukan sebagai perawi di kalangan ulama hadits.

Kedua, adanya penilaian dari para kritikus rawi yang menjelaskan berbagai aspek keunggulan dan kekurangan yang ada pada diri seorang perawi.

Ketiga, berlakunya kaedah alJarh wa al-Ta'dil ketika terjadi kontroversi para kritikus rawi dalam menilai seorang perawi.

Kemudian ditarik kesimpulan tentang kualitas seorang perawi berdasarkan konsederasi yang termaktub di atas, sehingga penilaian terhadap perawi tersebut dapat dipertanggungjawabkan dan mendapat legalitas.

\section{Perawi Bersifat Dhabith}

Ada tiga kategori khusus dalam melihat sifat dhabit dari seorang perawi yang dapat diterapkan oleh seorang ktitikus, yakni (a) tidak banyak melakukan kesalahan dan tidak lupa ketika meriwayatkan kembali hadits tertentu; (b) masih hafal ketika meriwayatkan kembali sebuah hadits dan (c) mengetahui makna hadits apabila meriwayatkannya melalui

\section{${ }^{7}$ Jalal al-Din 'Abd al-Rahman} Bin Bakr al-Suyuthi, Tadrib al-Rawi fi Syarh Taqrib al-Nawawi, Dar al-Ihya' alSunnah al-Nabawiyah, Beirut, 1979, Juz I, h. 63; Nuruddin 'Itr, Op/Cit., h. 344; 'A Ajjaj al-Khathib, Op.Cit., 1975, h. 305.

${ }^{8}$ M. Syuhudi Ismail, Op.Cit., 1993, 
makna ${ }^{9}$. Sementara metode kritik yang dapat diterapkan ketika melihat sifat dhabith seorang perawi adalah sebagai berikut: ulama.

Pertama, adanya kesaksian

Kedua, antara riwayat dari seorang perawi dengan riwayat perawi lain yang sudah cukup dikenal sifat dhabit- nya mempunyai kesesuaian dan kesamaan. Akan tetapi, tingkat kesesuaian dan kesamaan ini hanya berlaku pada makna dan harfiahnya saja.

Setalah itu, penarikan kesimpulan dapat dilakukan setelah diketahui otentisitas nilai dari kesaksian sumber dan perbandingan kajian intern sanad, sehingga sifat dhabith dari seorang perwai dapat diterima.

\section{Terhindar dari Syadz}

Para ulama berbeda pendapat dalam menyikapi terjadinya syadz dalam suatu sanad, namun acuan umum yang dapat dilakukan bertitik tolak dari rumusan Imam al-Syafi'iy yang menjelaskan bahwa: "apabila suatu hadits diriwayatakan oleh seorang perawi yang "Tsiqah", sedangkan perawi "Tsiqah" yang lain tidak ikut meriwayatakn hadits tersebut. Suatu hadits dapat dinyatakan sebagai syadz, apabila hadits yang diriwayatkan seorang perawi yang "Tsiqah" bertentangan dengan hadits yang diriwayatkan oleh banyak perawi yang juga "Tsiqah"10. Dengan demikian, sanad yang pertama dinilai sebagai $s y a d z$, sedangkan yang lebih kuat disebut mahfudz. Atas dasar itu, ada tiga kategori yang dapat dilakukan

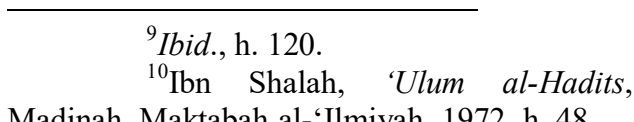

oleh seorang kritikus ketika melihat kriteria syadz ini:

Pertama, semua matan hadits yang mempunyai pokok permasalahan sama yang ada pada masing-masing sanad diambil dan dikumpulkan untuk disatukan, dan kemudian dilihat perbandingannya.

Kedua, meneliti kualitas semua perawi yang terdapat dalam jalur sanad.

Ketiga, apabila seluruh perawi dalam jalur sanad dinilai "Tsiqah", dan hanya satu orang sanad yang menyalahi sanad-sanad lainnya, maka sanad yang menyalahi tersebut dikelompokkan pada syadz, karena dikalahkan oleh sanad-sanad lain yang dikenal sebagai mahfudz.

Setelah dilakukan verifikasi melalui perbandingan kualitas dan kategorisai di atas, maka kesimpulan yang dapat diambil adalah proses penilaian hadits tersebut sudah bisa ditetapkan perawi yang syadz dan mahfud.

\section{Terhindar dari 'Illat}

Menurut Ibn Shalah, 'illat dimaksudkan sebagai sebab yang tersembunyi dan dapat merusak kualitas suatu hadits. Kebenaran dan munculnya 'illat dapat menyebabkan turunya nilai suatu hadits (tidak shahih) ${ }^{11}$. Atas dasar itu, maka seorang kritikus dapat mengetahui 'illat dengan memperhatikan beberapa kategori berikut ini ${ }^{12}$ :

Pertama, sanad yang tampak "muttashil" dan "marfu", ternyata setelah diselidiki "muttashil" dan "mauquf".

\footnotetext{
${ }^{11}$ Ibn Shalah, Op.Cit., h. 81 .

${ }^{12}$ M. Syuhudi Ismail, Op.Cit., 1993,
} 
Kedua, sanad yang tampak "muttashil" dan "marfu", ternyata setelah diselidiki "muttashil" dan "mursal".

Ketiga, terjadi percampuran sebuah hadits dengan hadits yang lainnya.

Keempat, terdapat kesalahan ketika menyebutkan perawi, karena terdapat adanya perawi-perawi yang mempunyai kemiripan nama, sedangkan kualitasnya berbeda dan tidak semuanya "Tsiqah".

Ketika menilai adanya cacat dalam sebuah hadits dengan berpatokan kepada kriteria terakhir ini ('illat), maka diperlukan bantuan kecerdasan, intuisi, hafalan hadits dalam jumlah yang banyak, pendalam pengetahuan tentang tingkat dhabith perawi serta mempunyai keilmuan dalam kajian sanad dan matan hadits.

Berbagai kriteria dan prosedur yang dilakukan oleh seorang kritikus di atas bila diterapkan secara concerns akan menempatkan posisi kajian sanad hadits sebagai "Shahih al-Isnad". Itulah sebabnya, ulama memberikan penilaian pada tingkat yang tinggi terhadap kritik sanad, karena kritik sanad dipandang lebih utama bila dibandingkan dengan kritik matan. Di samping itu, standar dalam kritik sanad dipandang sebagai telah baku, dan aplikasinya dinilai akurat melalui berbagai bukti yang telah disepakati.

\section{Posisi Sanad Dalam Ilmu Jarh Dan} Ta'dil

Secara etimologis, jarh merupakan mashdar dari kata jaraha yajrahu, yang berarti melukai. Baik luka yang berkenaan dengan fisik maupun non fisik. Kata jaraha bila digunakan hakim di pengadilan yang ditujukan pada masalah kesaksian memiliki makna tertentu, yakni menggugurkan keabsahan saksi ${ }^{13}$.

Secara terminologis, jarh didefenisikan oleh Muhammad 'Ajjaj al-Khatib sebagai "suatu sifat yang nampak pada perawi yang merusak ke'adil-an atau menjelekkan kehafalan dan kecermatannya, sehingga menyebabkan gugur atau lemah dan tertolak riwayat yang disampaikannya"14.

Adapaun ' $a d l$ secara etimologis berarti sesuatu yang dirasakan oleh diri bahwa dia itu dalam keadaan lurus. Secara terminologis adalah "orang yang tidak nampak dalam urusan keagamaan dan muru'ah-nya sesuatu yang menjelekkan ke-'adil-an dan muru'ah-nya"15. Dari kata 'adl ini muncul kata ta'dil, secara etimologis adalah mashdar dari kata 'addala yu'addilu, yang berarti mengemukakan sifat-sifat 'adil yang dimiliki oleh seseorang. Dan secara terminologis, berarti "mensifatkan perawi dengan sifat-sifat baik, sehingga nampak jelas ke- 'adil-an dan karenanya riwayat yang disampaikan dapat diterima" ${ }^{\text {"16 }}$.

Berdasarkan defenisi kata perkata dari jarh dan ta'dil di atas, maka dapat dipahami bahwa pengertian Ilmu Jarh dan Ta'dil adalah: "suatu ilmu yang membahas keadaan perawi hadits dari segi diterima atau ditolaknya periwayatan mereka". Dalam tataran operasionalnya, secara praktis ilmu Jarh dan Ta'dil dapat ditentukan melalui syarat-syarat dan

13، Ajjaj al-Khatib, Op.Cit., 1975, h. 260; M. Syuhudi Ismail, Op.Cit., h. 72; Ibn Manzur, Lisan al-Arab, Dar alMishriyah, Mesir, t.th., Juz II, h. 422-423.

${ }^{14}$ ‘ Ajjaj al-Khatib, Loc.Cit., 1975.

${ }^{15}$ Ibid., h. 260-261; Ibn Manzur, Op.Cit., Juz XIII, h. 457.

${ }^{16}$ Ibid. 
standar objektif. Penjelasan berikut ini berupaya untuk melihat lebih rinci mekanisme kerja dari ilmu ini.

\section{Syarat Kritikus Jarh dan Ta'dil}

Seorang kritikus harus memenuhi beberapa persyaratan guna menetapkan karateristik hadits melalui neraca Jarh dan Ta'dil. Persyaratan tersebut adalah: (1) berilmu, taqwa, wara' dan jujur; (2) mengetahui sebabsebab jarh dan ta'dil; (3) mengetahui penggunaan kalimat-kalimat bahasa Arab, sehingga suatu lafaz yang digunakan tidak diterapkan kepada makna yang lain ${ }^{17}$.

Berbagai persyaratan tersebut di atas menempati posisi yang sangat penting dalam rangka menentukan kewenangan seorang kritikus guna layaknya operasional Jarh dan Ta'dil. Sebaliknya, bila persyaratan tersebut tidak dipenuhi maka status individu kritikus tersebut tertolak dengan sendirinya, atau tidak dipercaya kredibilitasnya.

\section{Kode Etik Jarh dan Ta'dil}

Ada beberapa kode etik yang telah disepekati ketika seorang kritikus melakukan praktek Jarh dan Ta'dil. Kode etik tersebut dapat diurai sebagai berikut $^{18}$ :

Pertama, bersikap objektif, sehingga seorang kritikus tidak bersikap sepihak dengan meninggikan martabat seorang perawi dari yang sebenarnya atau merendahkannya.

Kedua, jarh tidak melebihi dari kebutuhan sebenarnya, karena jarh itu disyariatkan lantaran darurat, sementara sifat darurat ada batasnya.

${ }^{17}$ Nuruddin 'Itr, Op.Ct., h. 344.

${ }^{18}$ Ibid.
Ketiga, tidak hanya mengutip jarh apabila seorang perawi dinilai jarh oleh sebahagian kritikus, dan yang lain memberi penilaian ta'dil. Sikap yang demikian akan merampas hak seorang perawi yang bersangkutan. Bagi kalangan Muhadditsun sikap seperti ini sangat dicela.

Keempat, tidak melakukan jarh terhadap hal-hal yang tidak perlu dijarah-kan pada seorang perawi.

Kode etik ini diberlakukan guna mengantisipasi terhadap sikap negatif dan menghindari dari perkembangan praktis berlebih-lebihan dalam memberikan penilaian jarh dan ta'dil.

\section{Langkah-langkah Penetapan Jarh dan Ta'dil}

Ada beberapa prosedur yang dilalui dalam rangka memberikan penilaian jarh dan ta'dil. Prosedur ini ditetapkan sebagai langkah untuk menentukan status seorang perawi. Langkah-langkah yang dimaksud adalah $^{19}$ :

Pertama, pernyataan ke-'adil-an oleh dua ahli terhadap seorang perawi. Di kalangan Jumhur Ulama, dua kesaksian mereka ini dapat diterima karena dianalogikan kepada kesaksian hukum yang disyariatkan minimal dua orang saksi.

Kedua, dalam pandangan para perawi telah dikenal (masyhur) bahwa seorang perawi adalah "Tsiqah", atau sudah dikenal di kalangan ulama yang lain yang banyak memberikan pujian atas ke-Tsiqah-annya. Terhadap perawi yang demikian tidak dituntut adanya saksi.

Ketiga, penialian 'adil dari satu orang. Dalam kaitan ini, al-Baghdadiy, Ibn Shalah dan mayoritas peneliti

\footnotetext{
${ }^{19}$ Ibid.
} 
hadits melihat bahwa penilaian seperti ini dapat diterima walaupun dengan pernyataan satu orang saja.

Keempat, penilaian 'adil bagi seorang pengemban ilmu. Alasan yang diberikan 'Abd al-Barr adalah bahwa setiap pengemban ilmu yang dikenal loyalitasnya terhadap ilmu dipandang sebagai 'adil, kecuali bila diketemukan adanya bukti cacat dalam kehidupannya atau banyak melakukan kesalahan.

Berbagai persyaratan yang dikemukakan di atas merupakan suatu hal yang dituntut dalam memberikan penilaian jarh dan ta'dil untuk menentukan status seorang perawi hadits. Ini dilakukan dalam rangkan mencapai standar objektivitas dalam prosedur penilaian. Sedangkan upayaupaya yang dilakukan dalam penetapan jarh dan ta'dil diluar koridor persyaratan di atas dipandang sebagai suatu penyimpangan, dan berbagai konsekuensi yang ditimbulkan tidak diterima sebagai hasil dari proses tersebut. Upaya yang mungkin dilakukan diluar dari koridor yang dimaksud, antara lain dalam bentukbentuk berikut ini:

Pertama, penilaian ta'dil secara samar. Sebagai contoh, seorang perawi berkata; "seorang yang "Tsiqah" atau tidak, aku curigai menceritakan sesuatu kepadaku", tanpa menjelaskan nama seseorang tersebut. Dalam hal ini, penilaian tersebut tidak dapat diterima, sampai ia menjelaskan nama seorang yang dimaksud. Alasan yang digunakan adalah bila seorang tersebut dinilai "Tsiqah" oleh seorang perawi, namun ketika dijelaskan namanya bisa jadi seseorang itu di-jarh-kan oleh orang lain dalam bentuk mencacatkan, di samping itu menimbulkan keraguankeraguan bagi orang lain.
Kedua, menurut Ahli Hadits,
apabila seorang perawi 'adil meriwayatakan hadits dari orang lain yang dijelaskan namanya, belum dapat dikatakan sebagai ta'dil. Alasan yang dikemukakan bahwa perawi yang 'adil tersebut bisa saja meriwayatakan hadits dari seseorang yang "Tsiqah" atau tidak.

Ketiga, pengamalan dan fatwa dari seorang yang alim dan sesuai dengan yang diriwayatkannya belum tentu hadits itu dinilai shahih. Hal ini disebabkan bahwa pengamalan seorang alim tersebut yang sesuai dengan hadits bisa jadi disebabkan oleh kehatihatiannya atau karena ada dalil lain yang sesuai dengan hadits tersebut. Begitu pula sebaliknya, bila pengamalannya menyalahi hadits itu, bisa jadi karena ada salah satu kendala yang berat atau karena terjadi proses pen-ta'wil-an ${ }^{20}$.

\section{Tingkatan Jarh dan Ta'dil}

Dalam pandangan Ulama Hadits, seperti Ibn Hajar al-'Asqalaniy, masing-masing jarh dan ta'dil terdapat klasifikasi tingkatan. Pandangan Ibn Hajar tersebut, sebagaimana dikutip oleh Nuruddin 'Itr dianggap paling komprehensif dan sistematis di kalangan Ulama Hadits. Atas dasar itu, kalsifikasi dari tingkatan jarh dan ta'dil dimaksud dapat dijelaskan dalam uraian sebagai berikut ${ }^{21}$ :

Pertama, klasifikasi tingkatan ta'dil dikelompokkan kepada enam tingkatan. Masing-masingnya akan menentukan nilai dan status seorang perawi, yaitu:

Pertama, tingkat $t a$ 'dil tertinggi, yaitu sahabat.

\footnotetext{
${ }^{20}$ Ibid.

${ }^{21}$ Ibid.
} 
Kedua, tingkat ta'dil dengan menggunkan lafaz-lafaz yang menunjukkan ketinggian atau dengan menggunakan af'al al-tafdhil. Misalnya, autsaq al-nas, atsbat al-nas, adhbath al-nas, ilaihi al-muntaha fi altsabut. Kemudian kata-kata; man mitslu fulan atau fulan la yus'al 'anhu.

Ketiga, menggunakan lafaz ta'dil yang diulang-ulang, baik pengulangan ma'nawiy, seperti tsabtun hujjatun, tsabtun hafidzun tsiqatun tsabtun dan tsiqatun mutqinun. Kemudian pengulangan lafaz seperti tsiqatun tsiqah.

Keempat, lafaz ta'dil tunggal, seperti tsiqatun, tsabtun, mutqinun, kaannahu mushafun, hujjatun dan imamun.

Kelima, menggunakan lafazlafaz seperti laisa bihi ba'sun, la ba'sa bihi, shadqun, makmunun, khiyar alkhalqiy, ma a'lam bihi ba'sun atau mahaluhu al-shidqun.

Keenam, menggunakan lafazlafaz yang memberikan kesan jarh, seperti laisa bi ba'id min al-shawab, syaikhun, yurwa haditsuhu, tu'tabaru bihi, ruwiya 'anhu, shalih al- hadits, yuktabu haditsuhu, shaduq insya-Allah, hasan al- hadits, wasath dan lain-lain.

Status perawi yang berada pada salah satu tingkatan ta'dil di atas menempati kalsifikasi penilaian yang berbeda. Perawi yang berada pada tingkat pertama sampai tingkat keempat berstatus dapat dijadikan hujjah (dalil). Sementara perawi pada tingkat berikutnya (kelima dan keenam) tidak dapat dijadikan hujjah, karena lafaz yang ditujukan kepada mereka tidak menggambarkan nilai kedhabit-an, akan tetapi hadits yang mereka riwayatkan sekedar ditulis untuk dijadikan i’tibar.
Kedua, klasifikasi tingkatan jarh dapat dikelompokkan kepada enam tingkatan sebagai berikut:

Pertama, merupakan tingkat jarh yang paling ringan, seperti penggunaan lafaz dha'if, yunkaru marratan wa yu'rafu ukhra, laisa bi dzaka, laisa bi al-qawiy, laisa bi almatin, laisa bi hujjatain, laisa bi makmun, laisa bi mardhiyi atau kata yang dipergunakan sebahagian ulama saja, seperti layyin, takallamu fihi, math'un fihi atau fihi nazhar.

Kedua, menggunakan lafaz jarh, seperti ungkapan seseorang; fulan la yuhtaju bihi, dha'afahu, mudhtarif al- hadits, lahu ma yunkar, haditsuhu munkar, lahu manakir, dha'if atau munkar.

Ketiga, menggunakan lafaz jarh, seperti fulan rudda haditsuhu, mardud al- hadits, dha'if jiddan, laisa bi tsiqah, la yuktab haditsuhu, la tahillu kitabah haditsihi, la yusawi syaian, la yustasyhadu bi haditsihi dan lain-lain.

Keempat, adalah tingkat jarh yang menggunakan lafaz, seperti fulan yasriq al-hadits, matruk, dzahibt alhadits, tarakuhu, la yu'tabaru haditsuhu, laisa bi al-tsiqah, ghairu tsiqah, mudin dan lain-lain.

Kelima, menggunakan lafaz jarh, seperti al-dajjal, al-kadzdzab, alwadhdha', yadha'u dan wadha' alhadits.

Keenam, klasifikasi tingkatan jarh ini adalah menggunakan lafaz yang mengarah kepada tingginya nilai jarh seorang perawi, seperti akdzab alnas, huwa ruknu al-kidzib, ma'da alkidzib dan lain-lain.

Kesimpulan yang diambil dari klasifikasi tingkatan jarh di atas adalah bahwa hadits yang riwayatkan oleh perawi pada tingkat pertama dan kedua dari tingkat jarh dapat dipakai sebagai 
i’tibar, yakni dengan meneliti sejumlah perawi dalam jalur sanad lain yang dapat mendukung hadits tersebut untuk dapat dijadikan hujjah (dalil). Hal ini dilandasi kepada lafaz-lafaz yang digunakan pada dua tingkat tersebut menimbulkan kesan bahwa hadits yang bersangkutan dapat dijadikan i'tibar. Sedangkan hadits yang diriwayatakan para perawi yang berada pada tingkat selanjutnya (ketiga, keempat, kelima dan keenam) tidak dapat dipakai hujjah (dalil) dan i'tibar.

Dilandasi pada paparan di atas dapat dipahami bahwa kajian Jarh dan Ta'dil merupakan semangat ilmiah para pakar Ilmu Hadits yang tampak dari sikap mereka memberikan atensi yang cukup besar dan penekanan yang berulang-ulang tentang pentingnya sikap kritis terhadap sanad, sebagaimana pernyataan yang dikemukakan Muhammad Bin Sirin (w. $101 \mathrm{H}$ ): "Sanad hadits merupakan bagian dari agama, maka perhatikanlah dari siapa kamu mengambil agamamu"22. Juga pernyataan Abdullah Ibn Mubarak (w. 181 H): "Sanad hadits merupakan bagian dari agama, sekiranya sanad hadits tidak ada niscaya siapa saja akan bebas menyatakan apa yang dikehendakinya" ${ }^{, 23}$.

Secara tekstual, pernyataan dua tokoh Jarih dan Mu'addil di atas mengisyaratkan adanya anggapan di kalangan Ulama Hadits bahwa Ilmu

\footnotetext{
${ }^{22}$ Abu Husain Muslim Bin AlHajjaj al-Qusyairi, al-Jami' al-Shahih (Sahih Muslim), Disunting Kembali oleh Muhammad Fuad al-Baqi, Isa al-Babi alHalabi wa al-Syurakah, T.tp., 1955, h. 14.

${ }^{23}$ Ibid.; Muhammad al-Thahhan, Ushul al-Takhrij fi Dirasat al-Asanid, alMathba'ah al-'Arabiyah, Halb, 1978, h. 158.
}

Jarh dan Ta'dil yang merupakan sarana mempelajari keberadaan sanad diposisikan sebagai ilmu dalam lingkup empiris dan jangkauan manusia, sehingga apa yang diterima dari ilmu ini sebagai produk kajian rawi per rawi harus diiringi dengan sikap kritis. Itu sebabnya kajian Jarh dan Ta'dil dipandang sebagai semangat ilmiah yang dilandasi semangat religius dalam rangka melihat sosok upaya kritis para Jarih dan Mu'addil. Indikasi demikian terlihat dari: Pertama, adanya kejelasan penentuan objek dan kriteria objek yang dikaji (perawi). Dalam kaitan ini, para ahli Ilmu Hadits telah menetapkan bahwa perawi sebagai objek kajian Ilmu Jarh dan Ta'dil harus dinilai dari sisi kualitas pribadinya (ke- 'adil-annya, yang meliputi; Islam, mukallaf, melaksanakan ketentuan agama, dan memelihara muru'ah), serta kapasitas keilmuannya (ke-dhabith-annya, yakni; hafal dengan sempurna hadits yang diterimanya, mampu memahami dan menyampaikan kepada orang lain hadits yang diterima dan yang dihafalnya). Perawi yang 'adil dan dhabith-lah periwayatannya diterima. Di samping itu, Ulama Hadits juga menentukan keadaan yang merusak ke'adil-an perawi (suka berdusta, tertuduh suka berdusta, fasiq, tidak dikenal sebagai periwayat hadits atau al-jahalah, berbuat bid'ah) dan yang merusak ke-dhabith-an perawi (lebih sering salah dalam meriwayatkan hadis/fahusya ghalatuhu, lebih menonjol sifat lupanya/al-ghaflah 'an al-itqan, riwayat yang disampaikan bertentang dengan riwayat orang yang tsiqah, dan jelek hafalannya/su'u alhifzh) ${ }^{24}$.

\footnotetext{
${ }^{24 ،}$ Ali Bin Sultan al-Harawi alQari, Syarh Nukhbat al-Fikr, Dar al-Kutub
} 
Kedua, para ahli Ilmu Hadits juga menetapkan syarat-syarat yang harus dipenuhi untuk menjadi kritikus, yakni yang berkaitan dengan sikap pribadi (bersifat adil, tidak fanatik terhadap mazhab yang dianutnya, tidak bermusuhan dengan periwayat yang dinilainya) dan berkaitan dengan kapasitas kritikus (memiliki pengetahuan yang mendalam tentang ajaran Islam, Bahasa Arab, Hadits, Ilmu Hadits, pribadi periwayat yang dikritiknya, adat istiadat yang berlaku, serta sebab-sebab yang melatarbelakangi sifat terpuji dan tercela yang dimiliki perawi). Di samping itu juga ditentukan aturanaturan bagi kritikus dalam men-jarh dan men-ta'dil, di antaranya harus bersikap objektif, tidak berlebihlebihan dalam men-jarh maupun menta'dil dan menjelaskan sebab ketercelaan perawi.

Indikasi ketiga, sikap kritis Ulama Hadits nampak dengan adanya penjelasan kaedah-kaedah jarh dan ta'dil. Indikasi keempat ialah adanya metode tertentu dalam civitas Jarh dan Ta'dil, yakni metode komperasi melalui perbandingan (cross reference, silang rujuk) untuk saling konfirmasi keberadaan rawi per perawi baik antar kritikus maupun dengan dokumendokumen tertulis. Semua indikasi tersebut di atas menunjukkan bahwa pada dasarnya para kritikus tidak begitu saja menerima input tentang perawi tanpa diikuti seperangkat sikap yang kritis. Munculnya karya-karya di bidang jarh dan ta'dil, yakni sejak akhir abad II H merupakan bukti nyata semangat ilmiah dan kerja keras para Ulama Hadits terhadap studi perawi.

al-'Ilmiyah, Beirut, 1978, h. 159-160; M. Syuhudi Ismail, Op.Cit., h. 69-71.
Dari uraian di atas, terlihat bahwa melalui pendekatan ontologis semakin jelas kajian Ilmu Jarh dan Ta'dil di mata Filsafat Ilmu merupakan bagunan "ilmu" dalam lingkup empiris manusia dan bukan wewenang agama, serta tercakup dalam sub Ilmu Kemanusiaan (Human Sciences). Oleh sebab itu, Ilmu ini memposisikan diri sebagai "ilmu" yang memiliki metode tertentu yang sistematis dan mempunyai tata nilai kebenaran tertentu.

\section{Sanad Hadits Dalam Kawasan Sejarah}

Kata sanad berasal dari bahasa Arab, dari fi'il madhi, سند, dan fi'il mudhari', يسنـ . Bentuk pluralnya asnada dan sanada. Secara harfiah berarti sandaran. Apabila huruf س dan نdiberi harkat fathah, maka dalam tinjauan semantik artinya adalah seseorang bersandar pada sesuatu.

Secara terminologis, para ulama memberikan landasan pemahaman tentang sanad, dalam rangka mencoba melihat secara spesifik arti dan cakupan istilah tersebut, antara lain, seperti dikemukakan oleh kelompok Ahli Hadits, bahwa sanad merupakan jalan yang menghantarkan kita kepada matan hadits ${ }^{25}$. 'Ajjaj al-Khathib memberikan rumusan sanad sebagai penjelasan tentang jalan (rangkaian periwayat) yang menyampaikan kita kepada materi hadits ${ }^{26}$. Sebahagian ulama lain, sebagaimana yang dijelaskan oleh Abdul Hamid Muhammad Muhyiddin bahwa sanad

\footnotetext{
${ }^{25}$ Hasbi As-Shiddiqiy, Sejarah dan
} Pengantar Ilmu Hadis, Jakarta, Bulan Bintang, 1965, h. 163.

${ }^{26}$ 'Ajjaj al-Khatthib, Ushul al-Hadits: 'Ulumuhu wa Mushthalahuhu, Beirut, Dar alFikr, 1975, h. 32-33. 
adalah jalan yang bersambung yang sampai kepada matan hadits ${ }^{27}$. M. Syuhudi Ismail menjelaskan bahwa istilah sanad dapat dipahami sebagai rangkaian para periwayat yang menyampaikan riwayat hadits ${ }^{28}$.

Bila dilihat defenisi yang dikemukakan kalangan ulama di atas mempunyai pemahaman yang sama, dan hanya berbeda dalam redaksi yang dikemukakan. Intinya adalah bahwa sanad merupakan rangakaian mata rantai para perawi mulai dari perawi pertama sebagai penghimpun hadits sampai kepada materi (matan) hadits. Dalam kaitan ini, sanad merupakan suatu sistem yang saling berhubungan dan mempunyai pertalian erat dalam rangka periwayatan suatu hadits, sehingga dapat diyakini benar-benar berasal dan datang dari Rasulullah SAW.

Dalam perjalanan sejarah, sistem sanad bukan berasal dari tradisi Islam. Secara de facto dapat dilihat bahwa dari aspek metode yang diterapkan di dalam sanad ternyata sudah dipergunakan dalam rentang waktu yang cukup lama sebelum kedatangan agama Islam itu sendiri. Sebagai contoh, periwayatan puisipuisi Jahiliyah dari tradisi Arab klasik yang termaktub di dalam kitab Yahudi "Mishna", metode dan sistem sanad tersebut ternyata sudah diterapkan ${ }^{29}$. Meskipun demikian, sanad yang digunakan pada masa Jahiliyah

\footnotetext{
${ }^{27}$ Abdul Hamid Muhammad Muhyiddin, Syarh al-Fiyahal-Sayuthiy fiy Mushthalah al-Hadits, Mesir, Maktabah Tijariyah al-Kubra, T.th., h. 4.

${ }^{28} \mathrm{M}$. Syuhudi Ismail, Metodologi Penelitian Hadis Nabi, Jakarta, Bulan Bintang, 1993, h. 23.

${ }^{29}$ M. M. Azami, Hadits Nabawiy dan Sejarah Kodifikasinya, Jakarta, Pustaka Firdaus, 1994, h. 530.
}

tersebut, khususnya di kalangan Arab, tidak lain merupakan keharusan dan kebiasaan yang tidak terikat dengan sistem sanad itu sendiri. Dalam hal ini, H.A.R. Gibb menegaskan bahwa kebiasaan yang demikian merupakan kesetiaan pada adat-istiadat yang berlaku dalam budaya mereka ${ }^{30}$. Oleh sebab itu, mereka melakukan kegiatan transformasi puisi-puisi, cerita-cerita, kisah-kisah dan berbagai berita ditujukan pada peristiwa yang terjadi di kalangan mereka atau antar generasi yang terjadi dengan sendirinya, sehingga secara mekanis tanpa perlu pemahaman yang urgensi terhadap keharusan validitas penseleksian sanadnya.

Sementara penerapan sanad sebagai proses penseleksian hadits di dalam Islam, dimulai sejak kemunculan hadits itu sendiri, yakni masa Rasulullah SAW dan sahabatsahabatnya, meskipun dalam bentuk sederhana (belum sistematis) melalui "oral transmition", mutawatir, dari mulur ke mulut, dan berlansung secara spontanitas sebagai sarana dalam penyampaian hadits. Para sahabat, misalnya, ketika Nabi masih hidup mereka menyampaikan suatu riwayat hadits kepada sahabat yang lain setiap kali mereka bertemu. Secara tidak tertulis, ada kesepakatan di antara mereka bahwa bagi mereka yang menghadiri majlis Nabi SAW, dituntut untuk saling tukar menukar dan saling memberi informasi tentang apa yang didapati (didengar atau dilihat) kepada pihak yang tidak ikut serta dalam majlis tersebut. Sistem sanad yang diterapkan adalah, ketika mereka menyampaikan (meriwayatkan)

\footnotetext{
${ }^{30}$ H.A.R. Gibb, Mohamadanism and Historical Survey, London, Butler and Tunner, 1950, h. 73.
} 
kembali apa yang mereka dengar dan dilihat, selalu menyandarkan kepada Nabi SAW. Selanjutnya, apabila mereka meriwayatakan sesuatu yang tidak langsung diperoleh dari Nabi SAW, maka mereka tetap menjelaskan sumber darimana informasi tersebut diperoleh dan mereka terima.

Tradisi yang dilakukan oleh kalangan sahabat Nabi SAW dalam periwayatan hadits tersebut di atas, terus tumbuh dan berkembang baik di lingkungan Nabi SAW sendiri maupun di antara para sahabat. Bahkan masih tetap langgeng hingga Nabi SAW wafat. Akan tetapi kegiatan ini berhenti sampai tahun $40 \mathrm{H}$, dimana munculnya fitnah di kalangan sahabat sebagai dampak dari peperangan yang terjadi antara Khalifah Ali Ibn Abi Thalib dan Muawiyah Ibn Abi Sufyan, sehingga tradisi tersebut tidak dapat dipertahankan lagi sebagai model periwayatan hadits $^{31}$. Sebagai akibat dari perang saudara ini adalah bahwa periwayatan hadits tidak terlepas dari pengaruh sistem politik, ekonomi dan sosial yang berkembang. Atas dasar itu, para Ahli Hadits mulai menerima dan meneliti sumber dan karakter orang-orang yang terlibat dalam jalur sanad suatu hadits. Mereka sangat berhati-hati dalam meriwayatkan suatu hadits dan menseleksi secara ketat kriteria orang yang akan menerima serta kepada siapa hadits tersebut akan disampaiakan. Implikasi ilmiyah sebagai dampak dari perang saudara tersebut, sekaligus merupakan tonggak sejarah dalam penelitian dan perkembangan model sanad, yang dilanjutkan dengan penulisannya, dimulai pada akhir abad I H, dan secara sistematis ilmiyah mulai diterapkan

\footnotetext{
${ }^{31}$ Muhammad Rafiq, Sistem Isnad, Bandung, al-Ma'arif, 1980, h. 15-16.

secara sempurna pada kahir abad II $\mathrm{H}^{32}$.

Memang pada tempatnya bila dikatakan bahwa secara historis, sanad menempati posisi yang sangat urgensial, dimana ia berkembang setelah mendapat justifikasi sebagai bagian dari agama. Lebih jauh dapat dilihat di dalam tradisi kajian ilmu hadits, meskipun telah mengadopsi dari sistem sanad dan mengembangkannya secara optimal dalam budaya periwayatan hadits, tetapi sistem sanad tersebut telah mengakar secara internal dalam ilmu hadits.

\section{Penutup}

Secara eksplisit, penelitian atau kritik hadits yang selalu diarahkan pada kritik sanad (kritik eksternal; naqd alkhariji) dan kritik matan (kritik internal; naqd al-dakhili) pada dasarnya dilatarbelakangi oleh: (1) eksistensi hadits sebagai sumber hukum kedua yang perlu dipertahankan keotentikannya; (2) hadits belum ditulis secara lengkap pada masa Nabi SAW; (3) maraknya pemalsusan hadits; (4) proses penghimpunan hadits ke dalam kitab-kitab hadits yang memakan waktu lama; (5) banyaknya jumlah kitab-kitab hadits dengan metode penyusunan yang beragam; dan (6) diperbolehkannya periwayatan hadits bi al-ma'na.

Pada kritik sanad (naqd alkhariji), kajian senantiasa diarahkan pada kualitas para perawi dan metode periwayatan yang digunakan; apakah kredibilitas para perawi dan hadits tersebut diakui dan apakah 'adat tahammul dan ada'-nya menunjukkan bahwa ia hadits Nabi SAW. Sedang dalam kritik matan (naqd al-dakhili) 
lebih diarahkan pada ketentuanketentuan bahwa matan hadits tidak boleh bertentangan dengan al-Quran; hadits-hadits Mutawatir atau yang lebih tinggi kualitasnya; fakta sejarah; akal sehat; panca indera; serta terhindar dari syadz dan illat. Berangkat dari fokus kajian kritik sanad pada penilaian kualitas para perawi, maka keberadaan Ilmu Jarh dan Ta'dil mutlak diperlukan. Melalui ilmu inilah tersingkap penilaian para ulama kritikus terhadap diterima atau tidaknya periwayatan seorang perawi.

Diskursus yang muncul dalam penilaian kritikus terhadap perawi ialah adanya perbedaan kaedah yang dipegang kritikus dalam men-jarh dan men-ta'dil, serta seringnya terjadi perbedaan pandangan di kalangan kritikus tersebut. Sebagian menilai seorang perawi dengan predikat cacat, sementara yang lain menilai sebaliknya. Kenyataan kedua inilah yang membawa pada perbedaan sikap kritikus dalam menghadapi fenomena penilaian yang tidak seragam terhadap perawi yang sama; ada kritikus yang menentukan penilaian perawi berdasarkan pandangan mayoritas kritikus, ada pula yang didasarkan pada penilaian yang diiringi argumentasi yang jelas dan sebagainya.

Perlu untuk diresapi, bahwa para ulama hadits telah bekerja dan berupaya secara optimal dan maksimal dalam rangka meneliti, menseleksi dan membukukan sanad-sanad hadits berikut dengan matan-matan-nya dalam rentang waktu sejarah yang cukup panjang, sehingga tidak ada lagi keraguan bahwa upaya itu semua ternyata menjadi warisan yang tidak ternilai manfaat ilmiyahnya dalam rangka pemeliharaan kemurnian hadits Nabi SAW. Meskipun sempat terjadi pertikaian politik dan kegiatan pemalsuan hadits, khususnya dari segi sistem sanad-nya, itu semua tidak mengurangi semangat ketelitian dan penyelematan terhadap hadits.

\section{Daftar Pustaka}

Amin, Ahmad, Fajr al-Islam, Kairo, Maktabah al-Nahdhah alMishriyat, 1974.

As-Shiddiqiy, Hasbi, Sejarah dan Pengantar Ilmu Hadis, Jakarta, Bulan Bintang, 1965.

Abu Zakaria Yahya alNawawiy, Shahih Muslim bi Syarh alNawawiy, Kairo, Maktabah alMishriyat, 1924.

Azami, M. M., Hadits Nabawiy dan Sejarah Kodifikasinya, Jakarta, Pustaka Firdaus, 1994.

Gibb, H.A.R., Mohamadanism and Historical Survey, London, Butler and Tunner, 1950.

Ibn Chaldun, Muqaddimah, Beirut, Dar al-Fikr, T.th.

Ibn Manzur, Lisan al-'Arab, Dar al-Mishriyah, Mesir, t.th.

Ibn Shalah, 'Ulum al-Hadits, Madinah, Maktabah al-'Ilmiyah, 1972.

Ismail, M. Syuhudi, Kaedah Kesahihan Sanad Hadis, Telaah Kritis dan Tinjauan dengan Pendekatan Ilmu Sejarah, Jakarta, Bulan Bintang, 1988.

\footnotetext{
-------, Metodologi Penelitian Hadis Nabi, Jakarta, Bulan Bintang, 1993.

'Itr, Nuruddin, Manhaj al-Naqd fiy 'Ulum al-Hadits, Damaskus, Dar alFikr, 1979.
} 
Al-Khatthib, 'Ajjaj, Ushul alHadits: 'Ulumuhu wa Mushthalahuhu, Beirut, Dar al-Fikr, 1975.

Muhyiddin, Abdul Hamid Muhammad, Syarh al-Fiyahal-Sayuthiy fiy Mushthalah al-Hadits, Mesir, Maktabah Tijariyah al-Kubra, T.th..

Al-Qari, 'Ali Bin Sultan alHarawi, Syarh Nukhbat al-Fikr, Dar alKutub al-'Ilmiyah, Beirut, 1978.

Al-Qusyairi, Abu Husain Muslim Bin Al-Hajjaj, al-Jami' alShahih (Sahih Muslim), Disunting Kembali oleh Muhammad Fuad alBaqi, Isa al-Babi al-Halabi wa alSyurakah, T.tp., 1955.

Rafiq, Muhammad, Sistem Isnad, Bandung, al-Ma'arif, 1980.

Al-Shalih, Shubhi, 'Ulum alHadits wa Mushthalahuhu, Beirut, Dar al'Ilm li al-Malayin, 1977.

Al-Suyuthi, Jalal al-Din 'Abd al-Rahman Bin Bakr, Tadrib al-Rawi fi Syarh Taqrib al-Nawawi, Dar al-Ihya' al-Sunnah al-Nabawiyah, Beirut, 1979.

Al-Thahhan, Muhammad, Ushul al-Takhrij fi Dirasat al-Asanid, al-Mathba'ah al-'Arabiyah, Halb, 1978. 
104 Jurnal Ulunnuha Vol. 8 No.1/Juni 2019 